\title{
The signal crayfish is vulnerable to both the As and the Psl-isolates of the crayfish plague
}

\author{
H. Aydin ${ }^{(1)}$, H. Kokko(2) ${ }^{(2)}$ J. Makkonen ${ }^{(2)}$, R. Kortet ${ }^{(3)}$, H. Kukkonen ${ }^{(2)}$, \\ J. Jussila ${ }^{(2), \star \star}$
}

Received November 28, 2013

Revised February 3, 2014

Accepted February 4, 2014

Key-words: Aphanomyces astaci, susceptible signal crayfish, mortality, stress, molting

\section{ABSTRACT}

The carrier status and possible elevated tolerance of the signal crayfish (Pacifastacus leniusculus) against the crayfish plague disease agent (Aphanomyces astaci) has been speculated for several decades. We studied experimentally the responses of the signal crayfish from two Finnish populations against the crayfish plague infection by using two crayfish plague isolates with differing virulences; the highly virulent Psl-isolate and the mid virulent As-isolate. The studied signal crayfish came from two origins: the wild Leppävirta population and the Raukola farmed population of mixed genetic background. Both test groups were infected with $A$. astaci isolates using the challenge of 10000 spores $\mathrm{mL}^{-1}$. The isolates were PslPuujärvi (UEF8866-2) from Lake Puujärvi signal crayfish (year 2003) and As-Kivesjärvi (Evira6462/06) from Lake Kivesjärvi noble crayfish (year 2005 epidemic) in Finland. The crayfish were sampled prior to the experimental challenge with $A$. astaci to evaluate their $A$. astaci carrier status. The mortality, molting, feeding activity and other behavior of the crayfish were followed during the experiment. We observed increased mortality of the infected groups, related to the molting in some cases, and delayed molting. The impacts of the intense crayfish plague infection on the signal crayfish were clear and the studied populations showed differences in their reactions that are potentially explained by differing physiological conditions and different molt cycle phase. The results show that infection of both tested crayfish plague genotypes affects signal crayfish and is likely one of the main reasons behind losses among signal crayfish populations.

\section{RÉSUMÉ}

L'écrevisse signal est vulnérable aux deux génotypes As et Psl de la peste de l'écrevisse

Mots-clés : Aphanomyces astaci,
Le statut de porteur de l'écrevisse signal (Pacifastacus leniusculus) de l'agent de la peste des écrevisses (Aphanomyces astaci), et sa possible tolérance élevée à cet agent, a été soupçonné depuis plusieurs décennies. Nous avons étudié expérimentalement les réponses de l'écrevisse signal provenant de deux populations finlandaises à l'infection par la peste des écrevisses en utilisant deux isolats de

(1) The University of Kocaeli, Gazanfer Bilge MYO, 41500, Karamürsel, Kocaeli, Turkey

(2) Department of Biology, The University of Eastern Finland, Kuopio campus, P.O. Box 1627, 70211 Kuopio, Suomi-Finland

(3) Department of Biology, The University of Eastern Finland, Joensuu campus, P.O. Box 111, 80101 Joensuu, Suomi-Finland

^ Corresponding author: japo.jussila@uef.fi 
susceptibilité écrevisse signal, mortalité, stress, mue la peste de l'écrevisse de virulences différentes; le PSI- isolat très virulent et l'Asisolat moins virulent. L'écrevisse signal étudiée provient de deux origines : la population sauvage Leppävirta et celle de l'élevage d'écrevisses Raukola de fond génétique mélangé. Les deux groupes de test ont été infectés par $A$. astaci en utilisant une contamination par 10000 spores $\mathrm{mL}^{-1}$. Les isolats étaient PSI- Puujärvi (UEF8866-2) d'écrevisses signal du lac Puujärvi (année 2003) et As- Kivesjärvi (Evira6462/06) d'écrevisse noble du lac Kivesjärvi (épidémie 2005) en Finlande. Les écrevisses ont été échantillonnées avant expérimentation avec $A$. astaci pour évaluer leur statut de porteur d'A. astaci. La mortalité, la mue, l'activité alimentaire et d'autres comportements de l'écrevisse ont été suivis au cours de l'expérience. Nous avons observé une augmentation de la mortalité des groupes infectés, associée à la mue dans certains cas, et un retard de la mue. Les impacts d'une intense infection par la peste des écrevisses sur l'écrevisse signal étaient clairs et les populations étudiées ont montré des différences dans leurs réactions qui sont potentiellement expliquées par des différentes de conditions physiologiques et des phases du cycle de mue différentes. Les résultats montrent que l'infection des deux génotypes de peste des écrevisses testés affecte l'écrevisse signal et est probablement l'une des principales raisons de pertes parmi les populations d'écrevisses signal.

\section{INTRODUCTION}

The historical rationale for the introduction of the signal crayfish (Pacifastacus leniusculus) to Europe, and especially to Nordic countries including Finland, was their suspected high resistance against the crayfish plague infection (caused by Aphanomyces astaci) (Westman, 2000; Souty-Grosset et al., 2006). The assumptions were based on the co-existence of the pathogen and its host crayfishes in the North American continent for millions of years (Unestam, 1972; Hobbs, 1988), and on the preliminary studies that were carried out on the candidate stocks for the introductions (Unestam, 1969; Goldman, 1970; Abrahamsson and Goldman, 1970; Abrahamsson, 1973). The first documented epidemic of the crayfish plague in Europe was during late 19th century (Souty-Grosset et al., 2006), at least eight decades before the signal crayfish were introduced to Finland. In general, the discussions on the disease resistance in the signal crayfish were largely void in the early papers with some exceptions (e.g. Unestam, 1970, 1972, 1975). Since then, however, there has been direct experimental evidence (e.g. Thörnqvist and Söderhäll, 1995) and also anecdotal evidence from wild populations (e.g. Jussila et al., 2013a, 2013b, 2013c) indicating that the crayfish plague could have caused increased mortality among the wild signal crayfish stocks. These warnings have been largely ignored and the original assumption of the signal crayfish being able to resist the crayfish plague infection has been repeatedly brought up (Kirjavainen and Westman, 1999; Westman et al., 1999: Nylund and Westman, 2000). Unfortunately, this assumption has even been used, together with economical considerations, to ignore the basic guidelines of EU nature acts (e.g. EU 2013) when national alien species strategies have been drafted, a case example being the national alien species strategy in Finland (e.g. MMM, 2012).

The adaptation of the signal crayfish to Nordic conditions (climatic, environmental, ecosystemic, etc.), or the prevailing environmental stress, has been detected to possibly weaken its immune defense against crayfish plague and other co-existing opportunistic parasites (Thörnqvist and Söderhäll, 1993; Jussila et al., 2014; Edsman et al., manuscript in prep.). The infected signal crayfish stocks in Finland show multiple and severe gross symptoms (Jussila et al. 2013a,b), while these symptoms are not common among the crayfish plague infected stocks in North America. The different, unlikely optimal, environmental conditions and possibly a genetic bottleneck selection, even a founder effect, when a limited quantity of the signal crayfish was introduced (Westman, 1973), might have changed the original balance of host-pathogen relationship between the signal crayfish and the crayfish plague disease agent. The multiple gross symptoms observed in the Finnish and Swedish stocks give an 
impression that the interaction between the crayfish plague disease agent and the signal crayfish is drastically different when compared to Northern American populations. Moreover, as demonstrated by Thörnqvist and Söderhäll (1993), the signal crayfish can cope only with a limited number of pathogens and parasites even under optimal conditions. In their example an additional Psorospermium haeckeli infestation caused increased mortality of already $A$. astaci infected signal crayfish. Therefore, it is likely that multiple infections by different disease agents play a role in the system. The introduced signal crayfish may have to cope with some of the European parasites and pathogens. To understand the situation, and to evaluate how harmful different isolates of the crayfish plague disease agent might be to the signal crayfish, experimental detailed infection trials are needed.

The aim of our study was to assess the effects of intensive crayfish plague infection by two different $A$. astaci isolates on two Finnish signal crayfish stocks. We selected two potentially virulent $A$. astaci isolates from Finland (Makkonen et al., 2013) and a dose that reflects very intensive acute epidemic of the crayfish plague. After the experimental infections, we investigated the mortality rate, molting, feeding activity and other behaviors. The results of the present investigation could be used to better evaluate the attempts to justify further spread of the signal crayfish and the possible rationale of such activity. We were also interested in studying the potential background factors explaining wild signal crayfish stock collapses.

\section{MATERIALS AND METHODS}

\section{> THE SIGNAL CRAYFISH AND EXPERIMENTAL SYSTEM}

The signal crayfish were either 1) trapped from Lake Unnukka (Leppävirta) early June 2013 or 2) provided by a commercial crayfish farmer Raukola from Orivesi, Finland. The farmed stock is a genetic mixture from several stocks originating from the Southern Finland area. The crayfish were then stored in the University of Eastern Finland RapuLatorio crayfish facilities, in filtered Lake Kallavesi water at $18^{\circ} \mathrm{C}$ (proximately the same as in Lake Unnukka and Raukola farm ponds during trapping) and provided sweet corn ad libidum as food. Prior to being transferred into the experimental system, the crayfish were sexed, morphological measurements were taken and a part of the uropod was cut for initial infection level determination. The sampling has a minimal effect on the crayfish wellbeing and we have not observed increased mortality or loss of condition due uropod sampling in our previous studies. The crayfish were a minimum of $8 \mathrm{~cm}$ TL for both sexes, with a mean TL of $10.9 \pm 0.9 \mathrm{~cm}$ and $10.2 \pm 0.6 \mathrm{~cm}$ in Leppävirta and Raukola crayfish, respectively. The crayfish were at the beginning of growth period and thus about to molt when they were taken into the experimental system. The status and infestation level of $P$. haeckeli for the experimental crayfish was investigated after the experiment using method described by Henttonen (1996). None of the crayfish were infested by $P$. haeckeli.

The experimental system consisted of individual interconnected $2 L$ tanks with a recirculating filtered (Jussila et al., 2011a) Lake Kallavesi water with a flow that ensured full turnover of the $2 \mathrm{~L}$ tanks every hour (Jussila et al., 2013a).

\section{>PRODUCTION OF A. ASTACI SPORES AND THE CHALLENGE}

Two A. astaci isolates, Psl-Puujärvi (UEF8866-2) from Lake Puujärvi and As-Kivesjärvi (Evira6462/06) from Lake Kivesjärvi, both maintained in PG1-agar (Unestam, 1965), were used in the infection experiments. Isolates were characterised and genotyped with RAPD PCR (Viljamaa-Dirks et al., 2013) and with chitinase gene sequencing (Makkonen et al., 2012a). Details of the methods for zoospore production, modified after Cerenius et al. (1988), are explained in Makkonen et al. (2012b). The challenges of the crayfish were made in separate tanks for each experimental group. To trace back the individual data collected before the begin of the infection experiment, the individuals were numbered with permanent marker. 
The infection tanks contained $20 \mathrm{~L}$ of filtered Lake Kallavesi water, aeration and 10000 zoospores $\mathrm{mL}^{-1}$ added to the tank water. The time used for the challenge was $18 \mathrm{~h}$ and after that, the crayfish ( $N=12$ for each group) were dipped in clean water to remove the non-attached zoospores and then placed back into the individual monitoring tanks described earlier. Unchallenged but otherwise similarly to experimental crayfish treated crayfish were used as controls.

\section{> MANAGEMENT AND OBSERVATIONS OF THE INFECTION SYSTEM}

During the experiment crayfish were given sweet corn as food three times a week (Monday, Wednesday and Friday) and uneaten food remains were removed the following day. The water quality, dissolved oxygen, temperature and $\mathrm{pH}$, were monitored every other day during the experiment. Water quality remained within optimal range for crayfish throughout the study. The dissolved oxygen was $100.3 \pm 2.2 \%$ (min-max, 96.8-103.3\%), pH was $7.0 \pm 0.4$ (min-max, 6.3-7.2) and water temperature was maintained stable by room air conditioning at $20.8 \pm 1.0^{\circ} \mathrm{C}$ ( $\min -\max , 18.8-23.6^{\circ} \mathrm{C}$ ). During the experiment crayfish were monitored daily for moulting and behavioral symptoms indicating $A$. astaci infection (i.e. difficulties in maintaining orientation, paralysis, declining to eat, loosing limbs or claws) and mortalities. In case of mortalities, water circulation was closed and dead crayfish were removed from the tanks the following day.

Experimental crayfish were sampled prior to experimental challenge with $A$. astaci and either when they died in the experimental system or at the termination of the experiment by cutting tip of the uropod for qPCR analyses (Vrålstad et al., 2009) and the tissue samples were then processed and analysed following the protocol described by Jussila et al. (2011b).

\section{> STATISTICS}

Data was processed using MS Excel and SPSS ${ }^{\circledR}$ Statistics v. 19. The mortality rates among experimental groups were compared using Kaplan-Meier Log-Rank (Mantel-Cox) and experimental group means were compared using Mann-Whitney $U$ test or Fisher's exact test depending on the data. The criteria for the statistical significance was $p<0.05$.

\section{RESULTS}

\section{> MORTALITY, INFECTION LEVEL AND MOLTING AMONG INFECTED SIGNAL CRAYFISH}

During the experiment, we observed both $A$. astaci infection related mortality (Figure 1) and molting related mortality (Table I). The $A$. astaci infection related mortality was identified based on the gross symptoms prior to death and absence of molt while molt related mortality was the death happening during or right after the molt, i.e. up to two days after the molting. The crayfish in the $A$. astaci infected groups had both types of mortality and the control group, with elevated mortality in both populations, had only molting related mortality. This indicated that it would be beneficial to treat these two mortality cases separately. In statistical analyses as well as graphical presentation (Figure 1), we have divided the mortality data among these two categories.

We observed a statistically significant increase in the mortality of the Leppävirta signal crayfish infected with either the As-Kivesjärvi or the Psl-Puujärvi of the crayfish plague (Figure 1A) (Log Rank (Mantel-Cox): $\chi^{2}=5.576, p=0.018$ and $\chi^{2}=5.503, p=0.019$, respectively) during the 42 day experiment. The mortalities started in both infected groups three days after the challenge and an initial increase was also observed in the Leppävirta control group's mortality. The control group's mortality rate was also elevated. We also observed a difference in the 

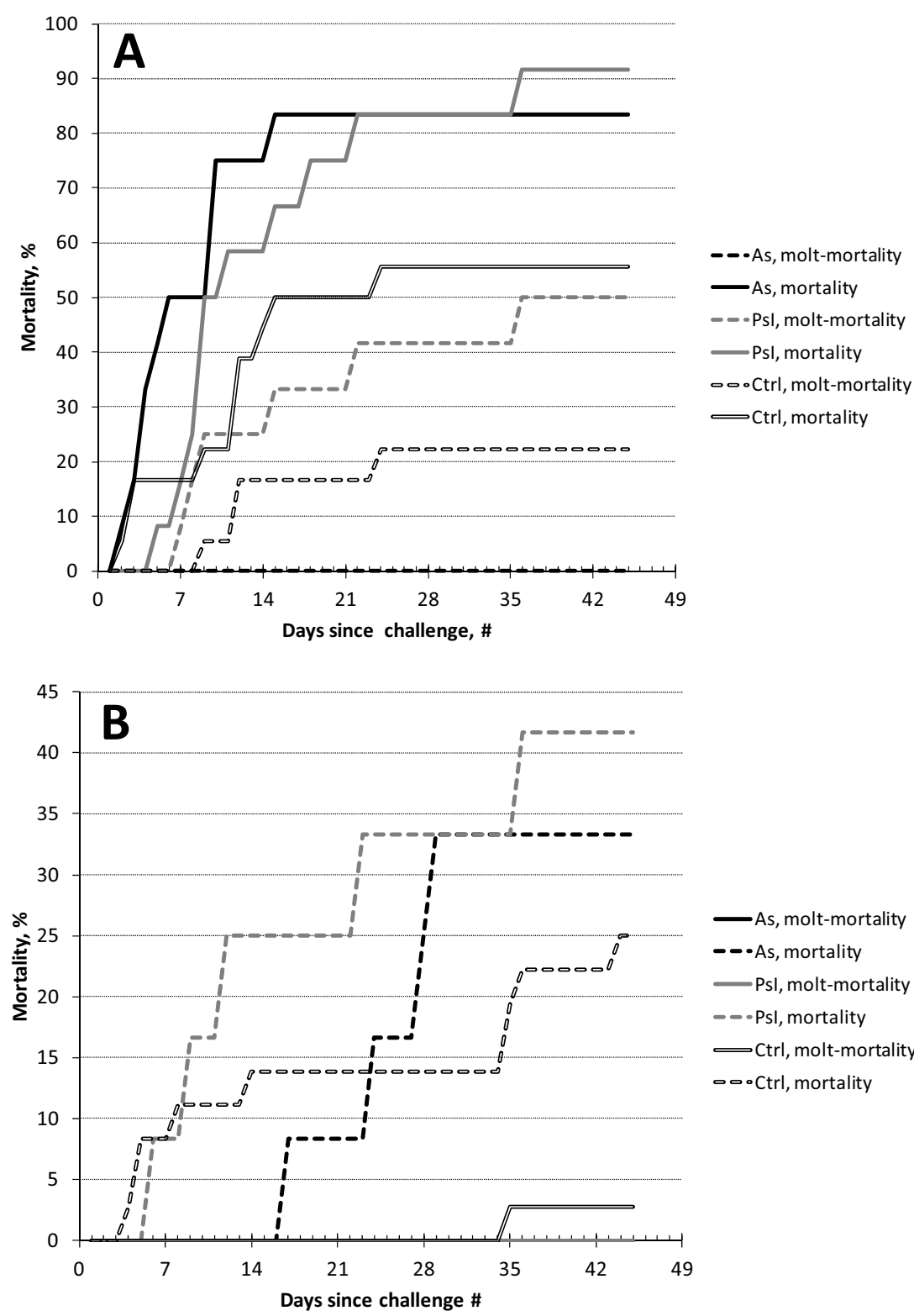

\section{Figure 1}

Mortality among As-Kivesjärvi or Psl-Puujärvi infected signal crayfish from two different populations. A is Leppävirta data and B is Raukola data. Symbols are: As = As-Kivesjärvi infected group; Psl = Psl-Puujärvi infected group; $\mathrm{Ctrl}=$ control group; mortality = death due to $A$. astaci infection and molt-mortality = death related to molting.

molt-related death rate between the As-Kivesjärvi and the Psl-Puujärvi infected Leppävirta crayfish groups, with the Psl-isolate infected group having a higher molt-related mortality (Log Rank (Mantel-Cox): $\chi^{2}=6.086, p=0.014$ ) as most of the crayfish in the As-Kivesjärvi infected group died before molting attemps. Similarly, the molting rate in the Leppävirta crayfish As-Kivesjärvi infected group was lower than in the Psl-Puujärvi infected or the control group (Table I), due to the As-Kivesjärvi infected Leppävirta signal crayfish dying before the molts, with two exceptions (Figure 1A).

The Raukola signal crayfish showed slightly but non-significantly elevated mortality among both As-Kivesjärvi and Psl-Puujärvi $A$. astaci infected crayfish groups (Log Rank (MantelCox): $\left.\chi^{2}<1.674, p>0.196\right)$ (Figure 1B). In both $A$. astaci infected groups, the mortality rate was similar, as well the timing of the deaths. The differences in timing of the deaths in different 


\section{Table I}

The percentage (\%) of successful molts, molting crayfish dying due to molt and molting time lag among the experimental groups, expressed as group mean. Different superscripts $(a, b$ and $c)$ in each column express statistically significant difference. Symbols in the table: * = two cases in this group; $1=$ Fisher's exact test and 2 = Mann-Whitney $U$ test.

\begin{tabular}{|l|c|c|c|}
\cline { 2 - 4 } \multicolumn{1}{c|}{} & ${ }^{1}$ Molts, $\%$ & ${ }^{1}$ Death at molt, $\%$ & ${ }^{2}$ Molt lag, days \\
\hline Leppävirta, As-Kivesjärvi & ${ }^{*} 16.7^{\mathrm{a}}$ & $0.0^{\mathrm{a}}$ & ${ }^{*} 15.0 \pm 14.1^{\mathrm{a}, \mathrm{b}}$ \\
\hline Leppävirta, PsI-Puujärvi & $50.0^{\mathrm{b}}$ & $54.5^{\mathrm{b}}$ & $12.7 \pm 10.9^{\mathrm{a}}$ \\
\hline Leppävirta, Ctrl & $78.9^{\mathrm{b}}$ & $42.1^{\mathrm{b}}$ & $14.7 \pm 10.3^{\mathrm{a}}$ \\
\hline Raukola, As-Kivesjärvi & $75.0^{\mathrm{b}}$ & $0.0^{\mathrm{a}}$ & $24.2 \pm 8.5^{\mathrm{b}}$ \\
\hline Raukola, Psl-Puujärvi & $58.3^{\mathrm{b}}$ & $0.0^{\mathrm{a}}$ & $28.7 \pm 5.5^{\mathrm{b}}$ \\
\hline Raukola, Ctrl & $66.7^{\mathrm{b}}$ & $2.8^{\mathrm{a}}$ & $25.4 \pm 8.6^{\mathrm{b}}$ \\
\hline
\end{tabular}

Raukola experimental groups were not statistically significant. We observed either no or very low death related mortalies among the Raukola crayfish experimental groups (Table I).

Several crayfish in all $A$. astaci challenged experimental groups lost their claws during the experiment a few days prior the death and normally ceased eating three to four days prior to death and became very passive. Molts were also preceded by fasting, normally a few days earlier than prior to death.

The initial background levels of the $A$. astaci infection in the Leppävirta group were $6.976 \pm$ 12.666 PFUs (agent level range of A2-A5 (Vrålstad et al., 2009)) and $282 \pm 495$ PFUs (A1-A4) in the Raukola group. There was a statistically highly significant difference between the groups (Mann-Whitney $U$ test, $p=0.041$ ). The final PFUs in the Leppävirta As-Kivesjärvi infected group were $166.583 \pm 258.435$ (A3-A6) and in the Leppävirta Psl-Puujärvi infected group they were $334.658 \pm 713.108$ (A4-A7). In the Raukola As-Kivesjärvi group the final PFUs were 74,622 $\pm 59,291$ (A3-A6) and in the Raukola Psl-Puujärvi infected group they were $44.641 \pm 66.456$ (A3-A6). There were no statistical differences among the infected group means, i.e. among both populations and both $A$. astaci challenged groups, in the final PFUs, while Raukola groups tended to show slightly lower PFUs. All the infected groups had significantly higher final PFUs compared to initial PFUs (Mann-Whitney $U$ test, $p<0.03$ ).

The molting rate was at a similar level in all experimental groups except for the Leppävirta As-Kivesjärvi infected group (Fisher's exact test) (Table I). Among that experimental group, only those As-isolate infected crayfish that survived the experiment were able to complete a molt or even attempt to molt. Among the Raukola signal crayfish experimental groups, the proportion of crayfish dying due molts was very low, zero with one exception, and similar to the Leppävirta As-Kivesjärvi infected group's molt related death rate. The Leppävirta PsIPuujärvi infected group's and control groups' molt related mortality was significatly higher than that of the other experimental groups in this study (Table I; Fisher's exact test, $p<0.05$ ). The molt time lag was roughly ten days longer among the Raukola crayfish compared to the Leppävirta crayfish, with a statistically significant difference between Leppävirta and Raukola groups (Mann-Whitney $U$ test, $p<0.05$ ), except for the Leppävirta As-Kivesjärvi infected group. There were no differences within the experimental populations in the molt time lag among the experimental groups (Table I; Mann-Whitney $U$ test, $p>0.05$ ), thus the $A$. astaci infection did not seem to affect timing of the molts.

\section{DISCUSSION}

Infection with both the As-Kivesjärvi and the Psl-Puujärvi $A$. astaci caused similar significantly elevated mortality among the Leppävirta signal crayfish and we observed a slight elevation in mortality also among the Raukola infected signal crayfish. Our results are in line with the earlier data reporting the crayfish plague associated elevated mortality among the signal crayfish (e.g. Thörnqvist and Söderhäll, 1995). However, in the earlier data, the genotype, if mentioned, is normally Psl or the crayfish have been additionally parasitized with $P$. haeckeli. The 
signal crayfish in our experiment did not have an additional parasitic load as stressor. According to our knowledge, the present data is the first to show that also As-genotype of the crayfish plague can infect the signal crayfish and also incur notably high mortalities. The earlier anecdotal evidence shows that the signal crayfish could die of the crayfish plague and even introductions might fail, as has been long debated and lately shown to happen in Nordic countries (e.g. Jussila et al., 2013b,c; FGFRI, 2013; Sahlin et al., 2010). The thorough evidence of the killer genotype still remains to be studied since both of the stocks in this experiment are chronic carriers of the crayfish plague, most probably the Psl-genotype. Further studies have been carried out to reveal the genotypes that the infected signal crayfish are expressing (unpublished).

The experiment was carried out in the early summer 2013, and due to warm spring and thus early initiation of the molting in these populations, we observed signs of stress which can also be seen in the Leppävirta control groups' high mortality rates. It is presumable that this physiological stress could have caused the more pronounced mortality among the Leppävirta signal crayfish. We also observed that those Leppävirta signal crayfish infected using the As-Kivesjärvi died prior to molting. We presume that the infection caused by As-Kivesjärvi in the already chronically infected signal crayfish could have caused proximate trauma which led to increased mortality during the premolt physiological processes. The co-effects of two simultaneous but different crayfish plague genotype infections needs to be further studied to understand the possible role of different $A$. astaci genotypes during the crayfish plague infection.

We have shown that the As-genotype crayfish plague can infect the signal crayfish, while the assumption has so far widely been that this is not the case and so far the diagnostic history indicates that the signal crayfish express only Psl-genotype in Finland (Viljamaa-Dirks et al., 2013). The question remains, whether the signal crayfish express only Psl-genotype even after challenge with the As-genotype and resulting increased mortality. The challenge, dosage of 10000 spores $\mathrm{mL}^{-1}$, was very high and could be obtained in the proximity of a noble crayfish releasing crayfish plague spores during acute infection (Makkonen et al., 2012b). The genotypes been expressed by the infected signal crayfish in this study will be further investigated at a later stage.

We observed a difference in both the $A$. astaci infection response and molting of the infected crayfish between Leppävirta and Raukola signal crayfish stocks. Crayfish from Leppävirta appeared to be more stressed at the initiation of the experiment, observed as a more lethargic performance, i.e. weaker response to handling. We observed also earlier molting initiation among Leppävirta stock during the experiment. Thus, we concluded that the later premolt stage, with crayfish having thin outer carapace with low $\mathrm{Ca}^{2+}$ content, among the Leppävirta stock could have made them more vulnerable to the crayfish plague infection, i.e. physiological changes and resource allocation could have caused the observed high mortality among the Leppävirta stock. This further emphasizes the possibility of the physiological challenge and environmental conditions having a crucial role in the fate of $A$. astaci infected signal crayfish.

Deaths at molt were practically absent among the Raukola stock signal crayfish with also a large proportion of those crayfish molting. In the Leppävirta stock, proportion of the crayfish molting was at a similar level among the control and the Psl-Puujärvi infected groups, while the molting related mortality rate among these groups was roughly $50 \%$. This also suggests that the additional infection together with the suspected physiological stress could have affected, in addition to infection mortality, also the rate of successful molting in the Leppävirta crayfish. Molting is one the key moments in crayfish life cycle. For the individuals weakened by infections, an increased mortality could result as a consequence of abnormal ambient conditions or compromised condition.

We detected a significant elevation of $A$. astaci DNA in the Leppävirta crayfish tissues during the experiment, while the Raukola crayfish showed less elevation of the disease agent quantity in their tissues. The reason for the difference could have been in the physiological condition of the two different stocks, a visual observation that was also indicated in the earlier 
molts among the Leppävirta signal crayfish. Crayfish in poor physiological condition could be more susceptible to diseases (Persson and Söderhäll, 1983; Söderhäll and Cerenius, 1992; Diéguez-Uribeondo et al., 1993; Edgerton et al., 2002; Royo et al., 2004). The high premolt mortality in the Leppävirta As-isolate infected group could indicate poor condition (e.g. Huner et al., 1990; Royo et al., 2004), similarly to how the high temperature stress and resulting loss of condition could compromise the following molt (Gladwell et al., 1976; Jussila, 1995). We did not study the effect of the physiological condition on the survival or other performance during the experiment, but the physiological condition could be a crucial issue in the disease resistance of the crayfish (Le Moullac and Haffner, 2000).

The slight difference between the infected Raukola groups and the control group mortality, even though not statistically significant, can be interpreted as elevated mortality which then would, under practical conditions and similarly to what was clearly observed in the Leppävirta infected groups, possibly result in a lower catch of the crayfishermen. The catch declines and fluctuations have been repeatedly reported by the Finnish crayfishermen trapping wild signal crayfish stocks (Edgerton and Jussila, 2004; Jussila et al., 2014). Thus, the factors causing wild signal crayfish stocks fluctuations should be further studied.

Signal crayfish have largely been considered as chronic carriers of crayfish plague (Souty-Grosset et al., 2006), while some of the stocks have been reported to be healthy, i.e. no detection of $A$. astaci in the surveys (Dunn et al., 2009; Kozubíková et al., 2009). Generally, the wild signal crayfish show gross symptoms of the crayfish plague infection, with also other opportunistic parasites infecting immuno compromised stocks (Edsman et al., 2013). The wild signal crayfish stocks thus possess routinely the disease, $A$. astaci infection, that could in case of additional stress cause increased mortality and even population collapses. Naturally, these alien chronic $A$. astaci carries also pose a major threat to the native European crayfishes (Bohman et al., 2006).

To conclude, we have shown that the signal crayfish could die of the crayfish plague infection, in case of both the As-genotype and the Psl-genotype infection. The compromised physiological condition, acting as a possible stressor during our experiment, seemed to increase the mortality rate. The differences observed in the mortality rates between the two signal crayfish populations in this study might have been indications of the fundamental differences among the Finnish, and wider, European signal crayfish stocks, which we have seen as differing responses of the wild signal crayfish stocks to crayfish plague infections. The present results indicate that the assumed role of the signal crayfish in the European crayfisheries should be carefully re-evaluated and further stockings of this alien crayfish should be critically considered. The chronic infections of the signal crayfish not only threaten native European crayfish but seem also to pose potential threat to the host signal crayfish.

\section{ACKNOWLEDGEMENTS}

The experiment was partially supported by the strategic funding of the University of Eastern Finland. Thanks to Satu Viljamaa-Dirks for A. astaci isolate Evira6462/06.

\section{REFERENCES}

Abrahamsson S., 1973. The crayfish Astacus astacus in Sweden and the introduction of the American crayfish Pacifastacus leniusculus. Freshw. Crayfish, 1, 28-40.

Abrahamsson S. and Goldman C.R., 1970. Distribution, density and production of the crayfish Pacifastacus leniusculus Dana in Lake Tahoe, California - Nevada. Oikos, 21, 83-91.

Bohman P., Nordwall F. and Edsman L., 2006. The effect of the large-scale introduction of signal crayfish on the spread of crayfish plague in Sweden. Bull. Fr. Pêche Piscic., 380-381, 1291-1302.

Cerenius L., Söderhäll K., Persson M. and Ajaxon R., 1988. The crayfish plague fungus, Aphanomyces astaci: diagnosis, isolation and pathobiology. Freshw. Crayfish, 7, 131-144. 
Diéguez-Uribeondo J., Pinedo-Ruíz J., Cerenius L. and Söderhäll K., 1993. Presence of Psorospermium haeckeli (Hilgendorf) in a Pacifastacus leniusculus (Dana) population of Spain. Freshw. Crayfish, 9, 286-288.

Dunn J.C., McClymont E.H., Christmas M. and Dunn A.M., 2009. Competition and parasitism in the native white clawed crayfish Austropotamobius pallipes and the invasive signal crayfish Pacifastacus leniusculus in the UK. Biol. Invasions, 11, 315-324.

Edgerton B.F., Evans L.H., Stephens F.J. and Overstreet R.M. 2002. Synopsis of freshwater crayfish diseases and commensal organisms. Aquaculture, 206, 57-135.

Edgerton B.F. and Jussila J., 2004. Keynote presentation and roundtable session 4. Crayfish pahology in Europe: past, present and a programme for the future. Bull. Fr. Pêche Piscic., 372-373, 473-482.

Edsman L., Nyström P., Sandström A., Stenberg M., Kokko H., Tiitinen V., Makkonen J. and Jussila J., 2014. Eroded swimmerets syndrome in female signal crayfish (Pacifastacus leniusculus), manuscript in preparation.

EU, 2013: Invasive alien species. http://ec.europa.eu/environment/nature/invasivealien/, visited 251113.

FGFRI, 2013. Täplärapu, kestävä ravustus ja rapuruton vaikutukset (Signal crayfish, sustainable crayfisheries and the effects of crayfish plague). http://www.rktl.fi/www/uploads/pdf/ RAPUTALOUSSEMINAARI_2013/5_taplarapu_kestava_ravustus_ja_rapurutto.pdf, visited 211113 (In Finnish).

Gladwell R.T., Bowler K. and Duncan C.J., 1976. Heat death in the crayfish Austropotamobius pallipesIon movements and their effects on excitable tissues during heat death. J. Thermal Biol., 1, 79-94.

Goldman C.R., 1970. Ecology and physiology of the California crayfish Pacifastacus leniusculus (Dana) in relation to its suitability for introduction into European waters. Freshw. Crayfish, 1, 105-120.

Henttonen P., 1996. The parasite Psorospermium in freshwater crayfish. Doctoral dissertation. Department of Applied Zoology \& Veterinary Medicine, University of Kuopio, Finland, 78 p.

Hobbs H.H., 1988. Crayfish distribution, adaptive radiation and evolution. In: Holdich, D.M., Lowery, R.S. (eds.), Freshwater Crayfish: Biology, Management and Exploitation, Croom Helm, London, 52-82.

Huner J.V., Könönen H. and Lindqvist O.V., 1990. Variation in body composition and exoskeleton mineralization as functions of the molt and reproductive cycles of the noble crayfish, Astacus astacus L. (Decapoda, Astacidae), from a pond in Central Finland. Comp. Biochem. Physiol., 96A), 235-240.

Jussila J., 1995. Notes on marron response to high temperature stress. ACWA, 9, 27-29.

Jussila J., Makkonen J. and Kokko H., 2011a. Peracetic acid (PAA) treatment is an effective disinfectant against crayfish plague (Aphanomyces astaci) spores in aquaculture. Aquaculture, 320, 37-42.

Jussila J., Makkonen J., Vainikka A., Kortet R. and Kokko H., 2011b. Latent crayfish plague (Aphanomyces astaci) infection in a robust wild noble crayfish (Astacus astacus) population. Aquaculture, 321,17-20.

Jussila J., Kokko H., Kortet R. and Makkonen J., 2013a. Aphanomyces astaci Psl-genotype isolates from different Finnish signal crayfish stocks show variation in their virulence but still kill fast. Knowl. Managt. Aquatic Ecosyst., 411, 10.

Jussila J., Tiitinen V., Fotedar, R. and Kokko H., 2013b. A simple and efficient cooling method for postharvest transport of the commercial crayfish catch. Freshw. Crayfish, 19, 15-19.

Jussila J., Makkonen J., Vainikka A., Kortet R. and Kokko H., 2014. Crayfish plague dilemma: how to be a corteous killer? Boreal Environ. Res., in print.

Kirjavainen J. and Westman K., 1999. Natural history and development of the introduced signal crayfish, Pacifastacus leniusculus, in a small, isolated Finnish lake, from 1968 to 1993. Aquat. Living Resour., 12, 387-401.

Kozubíková E., Filipová L., Kozák P., Ïuriš Z., Martín M.P., Diéguez-Uribeondo J., Oidtmann B. and Petrusek A., 2009. Prevalence of the crayfish plague pathogen Aphanomyces astaci in invasive American crayfishes in the Czech Republic. Conserv. Biol., 23, 1204-1213.

Le Moullac G. and Haffner P., 2000. Environmental factors affecting immune responses in Crustacea. Aquaculture, 191, 121-131.

Makkonen J., Jussila J. and Kokko H., 2012a. The diversity of the pathogenic oomycete (Aphanomyces astaci) chitinase genes within the genotypes indicate adaptation to its hosts. Fungal Gen. Biol., $49,635-642$. 
Makkonen J., Strand D.A., Kokko H., Vrålstad T. and Jussila J., 2012b. Timing and quantifying Aphanomyces astaci sporulation from the noble crayfish suffering from the crayfish plague. Vet. Mic., 162, 750-755.

Makkonen J., Kokko H., Vainikka A., Kortet R. and Jussila J., 2013. Dose-dependent mortality of the noble crayfish (Astacus astacus) to different strains of the crayfish plague (Aphanomyces astaci). J. Invertebr. Pathol., 115, 86-91.

MMM, 2013. Alien species in Finland. http://www.mmm.fi/en/index/frontpage/natural_resources/ invasive_alien_species.html. Visited 201113.

Nylund V. and Westman K., 2000. The prevalance of crayfish plague (Aphanomyces astaci) in two signal crayfish (Pacifastacus leniusculus) populations in Finland. J. Crustacean Biol., 20, 777-785.

Persson M. and Söderhäll K., 1983. Pacifastacus leniusculus Dana and its resistance to the parasitic fungus Aphanomyces astaci Schikora. Freshw. Crayfish, 5, 292-298.

Royo F., Andersson G., Banyeekhun E., Múzkuiz J.L., Söderhäll K. and Cerenius L., 2004. Physiological and genetic characterisation of some new Aphanomyces strains isolated from freshwater crayfish. Vet. Mic., 104, 103-112.

Sahlin U., Smith H.G., Edsman L. and Bengtsson G., 2010. Time to establishment success for introduced signal crayfish in Sweden - a statistical evaluation when success is partially known. J. Appl. Ecol., 47, 1044-1052.

Souty-Grosset C., Holdich D.M., Noël P.Y., Reynolds J.D and Haffner P. (eds.), 2006. Atlas of crayfish in Europe. Muséum national d'Histoire naturelle, Paris.

Söderhäll K. and Cerenius L., 1992. Crustacean immunity. Annu. Rev. Fish Dis., 2, 3-23.

Thörnqvist P-O. and Söderhäll K., 1993. Psorospermium haeckeli and its interaction with the crayfish defence system. Aquaculture, 117, 205-213.

Unestam T., 1965. Studies on the crayfish plague fungus Aphanomyces astaci I. Some factors affecting growth in vitro. Physiol. Plantarum, 18, 483-505.

Unestam T., 1969. Resistance to the crayfish plague in some American, Japanese and European crayfishes. Rept. Inst. Freshwat. Res., Drottingholm, 49, 202-209.

Unestam T., 1970. Significance of diseases on freshwater crayfish. Freshw. Crayfish, 1, 135-150.

Unestam T., 1972. On the host range and origin of the crayfish plague fungus. Rept. Inst. Freshw. Res. Drottningholm, 52, 192-198.

Unestam T., 1975. Defense reactions in crayfish towards microbial parasites, a review. Freshw. Crayfish, 2, 327-336.

Viljamaa-Dirks S., Heinikainen S., Torssonen H., Pursiainen M., Mattila J. and Pelkonen, S., 2013. Distribution and epidemiology of genotypes of the crayfish plague agent Aphanomyces astaci from noble crayfish Astacus astacus in Finland. Dis. Aquatic Organ., 103, 199-208.

Vrålstad T., Knutsen A.K, Tengs T. and Holst-Jensen A., 2009. A quantitative TaqMan ${ }^{\circledR}$ MGB real-time polymerase chain reaction based assay for detection of the causative agent of crayfish plague Aphanomyces astaci. Vet. Microbiol., 157, 146-155.

Westman K., 1973. The population of the crayfish Astacus astacus L. in Finland and the introduction of the American crayfish Pacifastacus leniusculus Dana. Freshw. Crayfish, 1, 41-55.

Westman K., 2000. Comparison of the crayfish Pacifastacus leniusculus Dana, a species introduced to Finland, with the native species, Astacus astacus L., in allopatry and sympatry. Doctoral dissertation. The University of Helsinki, Finland.

Westman K., Savolainen R. and Pursiainen M., 1999. Development of the introduced North American signal crayfish, Pacifastacus leniusculus (Dana), population in a small Finnish forest lake in 1970-1997. Boreal Env. Res., 4, 387-407. 